\title{
Layered double hydroxides: matrices for storage and source of boron for plant growth
}

\author{
GUSTAVO FRANCO DE CASTRO ${ }^{1}$, JADER ALVES FERREIRA ${ }^{2}$, \\ DENISE EULÁLIO ${ }^{2}$, SILAS JUNIOR DE SOUZA ${ }^{2}$, SARAH VIEIRA NOVAIS ${ }^{3}$, \\ ROBERTO FERREIRA NOVAIS ${ }^{2}$, FREDERICO GARCIA PINTO ${ }^{2}$ AND \\ JAIRO TRONTO ${ }^{2, *}$ \\ 'Universidade Federal de Viçosa, Campus de Viçosa, Departamento de Solos, Viçosa, CEP: 36570-900, Brazil \\ ${ }^{2}$ Universidade Federal de Viçosa, Instituto de Ciências Exatas e Tecnológicas, Campus de Rio Paranaíba, Rodovia \\ MG-230 km 08, Cx. Postal 22 - Rio Paranaíba - MG, CEP:38810-000, Brazil \\ 'Escola Superior de Agricultura "Luiz de Queiroz", Departamento de Ciências do Solo, Universidade de São Paulo, \\ Av. Pádua Dias, 11 - Cx. Postal 9 - Piracicaba - SP, CEP: 13418-900 - Brazil
}

(Received 5 October 2017; revised 27 February 2018; Guest Associate Editor: Vanessa Prevot)

\begin{abstract}
The increase of the absorption efficiency of boron (B) by plants is essential for increasing crop productivity. The intercalation of B in MgAl layered double hydroxides (LDHs) is an alternative to evaluating how these materials can provide $\mathrm{B}$ to plants. In this work, a MgAl LDH intercalated with borate ions $\left(\mathrm{Mg}_{2} \mathrm{Al}-\mathrm{B}-\mathrm{LDH}\right)$ was synthesized by the constant $\mathrm{pH}$ coprecipitation method, and the material produced was evaluated as a matrix for storage and as a source of $\mathrm{B}$ for plants. The $\mathrm{Mg}_{2} \mathrm{Al}$-B-LDH was characterized by XRD, ATR-FTIR, TGA-DTA, specific surface area, pore size and volume, and SEM. A bioassay was performed to verify the supply of B to plants from the two sources in the forms of $\mathrm{H}_{3} \mathrm{BO}_{3}$ and of $\mathrm{Mg}_{2} \mathrm{Al}-\mathrm{B}-\mathrm{LDH}$ to sunflower plants grown in pots. The $\mathrm{LDH}$ basal spacing value of $12.0 \AA$ is characteristic of intercalation of tetraborate octahydrate ions $\left[\mathrm{B}_{4} \mathrm{O}_{5}(\mathrm{OH})_{4}{ }^{2-}\right] \cdot 8 \mathrm{H}_{2} \mathrm{O}$ between the layers. There was an increase in the dry matter (DM) and B content of the plants relative to those treatments where no B was added. The lack of statistical difference for plant yield between the two sources of $\mathrm{B}$ suggests a lack of stability of the $\mathrm{Mg}_{2} \mathrm{Al}-\mathrm{B}-\mathrm{LDH}$ structure under the acidic condition of the soil.
\end{abstract}

KEYWORDS: slow-release fertilizer, plant nutrition, LDH matrix, micronutrient, bioassay.

Boron is a micronutrient used in plant growth and development (Marschner, 2012). Some of the B used as fertilizer is highly soluble and easily leached into the soil profile. This is particularly important in very rainy areas. While most clayey soils retain for longer periods the $\mathrm{B}$ added, this behaviour is also observed in soils

This paper was presented during session MISC-01-

'LDHs: from design and characterization to applications' at the International Clay Conference 2017.

*E-mail: jairotronto@ufv.br

https://doi.org/10.1180/clm.2018.6 with more organic carbon and greater ion exchange capacity (Rosolem \& Bíscaro, 2007). Thus, increase in the adsorption of this nutrient in the soil, for slow and gradual absorption by the plants, is essential for increasing agricultural productivity.

An alternative way to provide $B$ in a sustainable manner includes storage in layered inorganic materials. The intercalation of borate ions in LDH is of interest as a new form of storage and sustained release of B for plants (Benício et al., 2015; Guan et al., 2016).

The LDHs, also called hydrotalcite-type compounds, can be described structurally as the stacking of positively charged layers with hydrated anions in the 
interlamellar domain. To ensure a better understanding of the structure of $\mathrm{LDH}$, it is convenient to start with the brucite structure. In brucite, a $\mathrm{Mg}(\mathrm{OH})_{2}$ mineral, the $\mathrm{Mg}^{2+}$ cations are in the centre of octahedra which have hydroxyl anions at their vertices. These octahedra share their edges, forming flat and neutral layers held together by $\mathrm{H}$ bonds. When, in this type of structure, the $\mathrm{Mg}^{2+}$ cations are replaced isomorphically by trivalent cations, the layer has a positive residual charge. To acquire electroneutrality, the system requires the presence of anions between the layers, which, alongside $\mathrm{H}_{2} \mathrm{O}$ molecules, promote the stacking of double hydroxide layers with an orderly interlamellar domain (Cavani et al., 1991; de Roy et al., 1992; Evans \& Slade, 2006; Forano et al., 2006). The general formula $\left[M_{1-x}^{2+} M_{x}^{3+}(\mathrm{OH})_{2}\right] A_{x / m}^{m-} \cdot n \mathrm{H}_{2} \mathrm{O}$ characterizes these materials, in which $M^{2+}$ represents a bivalent cation, $M^{3+}$ represents a trivalent cation, and $A^{m-}$ represents an anion with $m$-charge.

In the agricultural field, LDHs have been used in the intercalation of pesticides, herbicides, plant-growth hormones, as well as the intercalation of nutrients such as nitrate, phosphates $\left(\mathrm{PO}_{4}{ }^{3-}, \mathrm{HPO}_{4}{ }^{2-}, \mathrm{H}_{2} \mathrm{PO}_{4}{ }^{-}\right)$, etc. to obtain matrices that have a sustained release of the intercalated anions (Tronto et al., 2004; Cardoso et al., 2006; Ghormade et al., 2011; da Silva et al., 2014; Benício et al., 2016; Everaert et al., 2016, 2017; Halajnia et al., 2016; Yu et al., 2017).

Woo et al. (2011) studied the synthesis, characterization and kinetics of release of phosphate ions intercalated in CaFe-LDH. Those authors suggested the importance of this material as a slow-release phosphate fertilizer and as a soil acidity neutralizer, although they did not conduct any experiments with plants to verify the actual effectiveness of the LDH produced. Everaert et al. (2017) noted that, although Mg-Al-LDH has a reduced agronomic potential compared to monoammonium phosphate (MAP) after being incubated with wheat plants, this material has environmental benefits such as $\mathrm{P}$ reuse and residue use, thus being attractive for use as a slow-release fertilizer. To compare P-LDH with triple superphosphate in a Neubauer experiment, Benício et al. (2016) noted an increase in plant mass and height, as well as the total P content in the DM (the weight of the plant when completely dried). The increase of soil $\mathrm{pH}$ in P-LDH treatments was the main contributor to the reduction of soil $\mathrm{P}$ adsorption.

Previous work has shown that the treatment of LDH to impart slow release of nutrients is of chemical and mineralogical nature, and suggested its applicability as a source of slow-release nutrients without, however, presenting conclusive bioassay results on this application (Berber et al., 2014; Imran et al., 2016; Moraes et al., 2016; Ashekuzzaman et al., 2017). The present work thus has the following objectives: (1) to synthesize and characterize a $\mathrm{Mg}$ and $\mathrm{Al}$ LDH intercalated with borate ions $\left(\mathrm{Mg}_{2} \mathrm{Al}-\mathrm{B}-\mathrm{LDH}\right)$; and (2) to evaluate, by bioassay, the potential of the material produced for use as a matrix for storage and sustained release of B for plants.

\section{MATERIAL S}

All reagents used in this work have a degree of analytical purity. $\mathrm{Mg}\left(\mathrm{NO}_{3}\right)_{2} \cdot 6 \mathrm{H}_{2} \mathrm{O}$ (purity $>98 \%$ ) was purchased from Vetec; $\mathrm{Al}\left(\mathrm{NO}_{3}\right)_{3} \cdot 9 \mathrm{H}_{2} \mathrm{O}$ (purity $>98 \%$ ) was purchased from Sigma-Aldrich; $\mathrm{H}_{3} \mathrm{BO}_{3}$ (purity > 99.5\%) was purchased from Exxodo Científica, and $\mathrm{NaOH}$ ( purity $=99 \%$ ) was purchased from Vetec. The water used in the synthesis reactions was distilled and/ or deionized (Milli-Q ${ }^{\circledR}$ system), according to the needs of its use.

\section{LDH synthesis}

The preparation of $\mathrm{Mg}_{2} \mathrm{Al}-\mathrm{B}-\mathrm{LDH}$ was carried out by the constant $\mathrm{pH}$ coprecipitation method (De Roy et al., 1992). In this method, $250 \mathrm{~mL}$ of a solution containing $1.0 \mathrm{~mol} \mathrm{~L}^{-1}$ of $\mathrm{Mg}\left(\mathrm{NO}_{3}\right)_{2} \cdot 6 \mathrm{H}_{2} \mathrm{O}$ and $0.5 \mathrm{~mol} \mathrm{~L}^{-1}$ of $\mathrm{Al}\left(\mathrm{NO}_{3}\right)_{3} \cdot 9 \mathrm{H}_{2} \mathrm{O}$ was added dropwise, under vigorous stirring, to $500 \mathrm{~mL}$ of a solution containing $1.25 \mathrm{~mol} \mathrm{~L}^{-1}$ of $\mathrm{H}_{3} \mathrm{BO}_{3}$. The synthesis was carried out under $\mathrm{N}_{2}$ atmosphere to eliminate the influence of atmospheric carbon dioxide. During the synthesis, a $2.0 \mathrm{~mol} \mathrm{~L}^{-1} \mathrm{NaOH}$ solution was added to maintain the $\mathrm{pH}$ value at $10.0 \pm 0.5$. This $\mathrm{pH}$ value usually presents highly satisfactory results, obtaining MgAl-LDHs with good structural organization and phase purity (De Roy et al., 1992). After the synthesis, the solid material was washed with $\mathrm{H}_{2} \mathrm{O}$ and dried under vacuum in the presence of silica gel.

\section{Characterization of the sample}

To characterize $\mathrm{Mg}_{2} \mathrm{Al}-\mathrm{B}-\mathrm{LDH}$, the following analysis techniques were used: X-ray powder diffraction (XRD), attenuated total reflectance Fourier transform infrared spectroscopy (ATR-FTIR), simultaneous thermogravimetric and differential thermal analysis (TGA-DTA), specific surface area (by the Brunauer Emmet Teller method (BET)), scanning electron microscopy (SEM), and ultraviolet-visible molecular absorption spectrophotometry (UV-Vis).

For the XRD analysis, a sample of $\mathrm{Mg}_{2} \mathrm{Al}-\mathrm{B}-\mathrm{LDH}$ was macerated to obtain particles of uniform size. 
A Shimadzu XRD-6000 instrument, with a copper cathode and a graphite monochromator, with a wavelength of $1.5406 \AA$, was used, at $30 \mathrm{kV}$ and $30 \mathrm{~mA}$. A scanning step of $0.01^{\circ}$, and $10 \mathrm{~s}$ per step were used and the scanning range was $4-7^{\circ} 2 \theta$. The same instrument and conditions were used to characterize the soil mineralogy used in the bioassay. The ATR-FTIR spectrum was recorded on a Jasco FTIR 4100 spectrophotometer. The spectrum was obtained with 256 scans, over a wavelength range of 4000 to $400 \mathrm{~cm}^{-1}$. Simultaneous TGA-DTA analyses were performed using an SDT 2960 Simultaneous DTATGA thermal analyzer (TA Instruments), at a heating rate of $10^{\circ} \mathrm{C} \mathrm{min}{ }^{-1}$, with a dry synthetic air flow $(80 \%$ $\mathrm{N}_{2}$ and $20 \% \mathrm{O}_{2}$ ) of $100 \mathrm{~cm}^{3} \mathrm{~min}^{-1}$, in the temperature range of $30-1000^{\circ} \mathrm{C}$. The amount of sample mass used was approximately $10 \mathrm{mg}$. The BET surface area of the $\mathrm{Mg}_{2} \mathrm{Al}-\mathrm{B}-\mathrm{LDH}$ was determined with $\mathrm{N}_{2}$ adsorption using a ChemBET Pulsar TPR/TPD device (Quantachrome Instruments $^{\mathcal{O}}$ ).

The SEM imaging was carried out on a Carl Zeiss EVO 50 microscope. The sample, in powder form, was supported on the sample holder by dispersion on a conductive double-sided adhesive tape. Gold coating was applied to the samples prior to measurement using a Bal-Tec SCD 050 Sputter Coater spray. The concentration of borate in $\mathrm{Mg}_{2} \mathrm{Al}-\mathrm{B}-\mathrm{LDH}$ was determined with Ultraviolet-Visible Molecular Absorption Spectrophotometry (UV-Vis), $\lambda=420 \mathrm{~nm}$, in a Thermo Scientific Evolution 300 device. The B available in the soil was determined according to López et al. (1993). A soil sample for the bioassay was collected at $0-20 \mathrm{~cm}$ depth in a Dystrophic Red Latosol (DRL), an Oxisol (USDA, 1999), with a clay-like texture, in the region of the city of Rio Paranaíba (MG). The sample was air-dried, levelled and sieved with a 4-mm mesh sieve. After drying, the sample was homogenized. A sub-sample of this soil was removed and sieved using a 2-mm mesh sieve, obtaining air-dried fine earth (ADFE). The chemical and physical characteristics of the sample are presented in Table 1 and the mineralogical characterization is presented in Fig. 1a.

\section{Kinetics of boron adsorption}

To evaluate the stability of B adsorption in the soil, an assay was conducted to evaluate the effect of the contact time of increasing doses of this micronutrient on the soil. For this test, $0.00,10.00$ and $20.00 \mathrm{mg} \mathrm{dm}^{-3}$ of total $\mathrm{B}$ were used in the soil, in the forms of $\mathrm{H}_{3} \mathrm{BO}_{3}$ and $\mathrm{Mg}_{2} \mathrm{Al}-\mathrm{B}-\mathrm{LDH}$. The sources, in their doses, were
TABLE 1. Chemical and physical characteristics of the soil sample.

\begin{tabular}{|c|c|}
\hline Attribute & DRL \\
\hline $\mathrm{pH}_{\mathrm{H}_{2} \mathrm{O}} *$ & 5.04 \\
\hline $\mathrm{P}\left(\mathrm{mg} \mathrm{dm}^{-3}\right)$ & 0.90 \\
\hline $\mathrm{K}\left(\mathrm{mg} \mathrm{dm}^{-3}\right)$ & 22.00 \\
\hline $\mathrm{Ca}^{2+}\left(\mathrm{cmol}_{\mathrm{c}} \mathrm{dm}^{-3}\right)$ & 0.23 \\
\hline $\mathrm{Mg}^{2+}\left(\mathrm{cmol}_{\mathrm{c}} \mathrm{dm}^{-3}\right)$ & 0.07 \\
\hline $\mathrm{Al}^{3+}\left(\mathrm{cmol}_{\mathrm{c}} \mathrm{dm}^{-3}\right)$ & 0.50 \\
\hline $\mathrm{H}+\mathrm{Al}\left(\mathrm{cmol}_{\mathrm{c}} \mathrm{dm}^{-3}\right)$ & 9.40 \\
\hline $\mathrm{SB}\left(\mathrm{cmol}_{\mathrm{c}} \mathrm{dm}^{-3}\right)$ & 0.36 \\
\hline $\mathrm{t}\left(\mathrm{cmol}_{\mathrm{c}} \mathrm{dm}^{-3}\right)$ & 0.86 \\
\hline $\mathrm{T}\left(\mathrm{cmol}_{\mathrm{c}} \mathrm{dm}^{-3}\right)$ & 9.76 \\
\hline V (\%) & 3.70 \\
\hline m (\%) & 58.10 \\
\hline $\mathrm{OM}\left(\mathrm{dag} \mathrm{kg}^{-1}\right)$ & 4.94 \\
\hline P-rem $\left(\mathrm{mg} \mathrm{L}^{-1}\right)$ & 6.70 \\
\hline $\mathrm{S}\left(\mathrm{mg} \mathrm{dm}^{-3}\right)$ & 6.80 \\
\hline $\mathrm{B}\left(\mathrm{mg} \mathrm{dm} \mathrm{m}^{-3}\right)$ & 0.23 \\
\hline $\mathrm{Cu}\left(\mathrm{mg} \mathrm{dm}^{-3}\right)$ & 0.97 \\
\hline $\operatorname{Mn}\left(\mathrm{mg} \mathrm{dm}^{-3}\right)$ & 2.50 \\
\hline $\mathrm{Fe}\left(\mathrm{mg} \mathrm{dm}^{-3}\right)$ & 68.90 \\
\hline $\mathrm{Zn}\left(\mathrm{mg} \mathrm{dm}^{-3}\right)$ & 0.48 \\
\hline Coarse sand $\left(\mathrm{kg} \mathrm{kg}^{-1}\right)$ & 0.064 \\
\hline Fine sand $\left(\mathrm{kg} \mathrm{kg}^{-1}\right)$ & 0.058 \\
\hline Silt $\left(\mathrm{kg} \mathrm{kg}^{-1}\right)$ & 0.109 \\
\hline Clay $\left(\mathrm{kg} \mathrm{kg}^{-1}\right)$ & 0.769 \\
\hline Textural Classification & Very clayey \\
\hline
\end{tabular}

*soil/water ratio 1:2.5; $\mathrm{P}, \mathrm{K}, \mathrm{Cu}, \mathrm{Mn}, \mathrm{Fe}$ and $\mathrm{Zn}-$ Mehlich-1 extractor; $\mathrm{Ca}^{2+}, \mathrm{Mg}^{2+}$ and $\mathrm{Al}^{3+}-1.0 \mathrm{~mol} / \mathrm{L}$ $\mathrm{KCl}$ extractor; S-Extractor $\mathrm{Ca}\left(\mathrm{H}_{2} \mathrm{PO}_{4}\right)_{2}, 500 \mathrm{mg} / \mathrm{L}$ of $\mathrm{P}$ in HOAc $2 \mathrm{~mol} / \mathrm{L}$; B - "Hot water" extractor; H + Al Calcium Acetate Extractor $0.5 \mathrm{~mol} / \mathrm{L}(\mathrm{pH} 7.0) ; \mathrm{SB}=$ sum of bases; $\mathrm{t}=$ effective cation exchange capacity; $\mathrm{T}=$ cation exchange capacity at $\mathrm{pH}=7 ; \mathrm{V}=$ base saturation; $\mathrm{m}=$ saturation by $\mathrm{Al} ; \mathrm{OM}=$ organic matter; $\mathrm{P}$-rem = remaining phosphorus; DRL = Dystrophic Red Latosol.

homogenized thoroughly with the soil. Plastic bags were filled with treatments (soil $+\mathrm{B}$ sources) and received distilled $\mathrm{H}_{2} \mathrm{O}$ in a volume equivalent to soil field capacity (FC). They were then closed to prevent water loss. Every 2 days, checks were made to verify that the plastic bags with the treatments maintained their initial weights; if they had not, they were topped up with distilled $\mathrm{H}_{2} \mathrm{O}$. The contact times for each soil sample with the B sources were 1, 2, 3, 5, 10, 20 and 40 days. After this contact time, the treatment samples were duly dried, and the available B content in the soil was determined by the hot-water extraction method in 


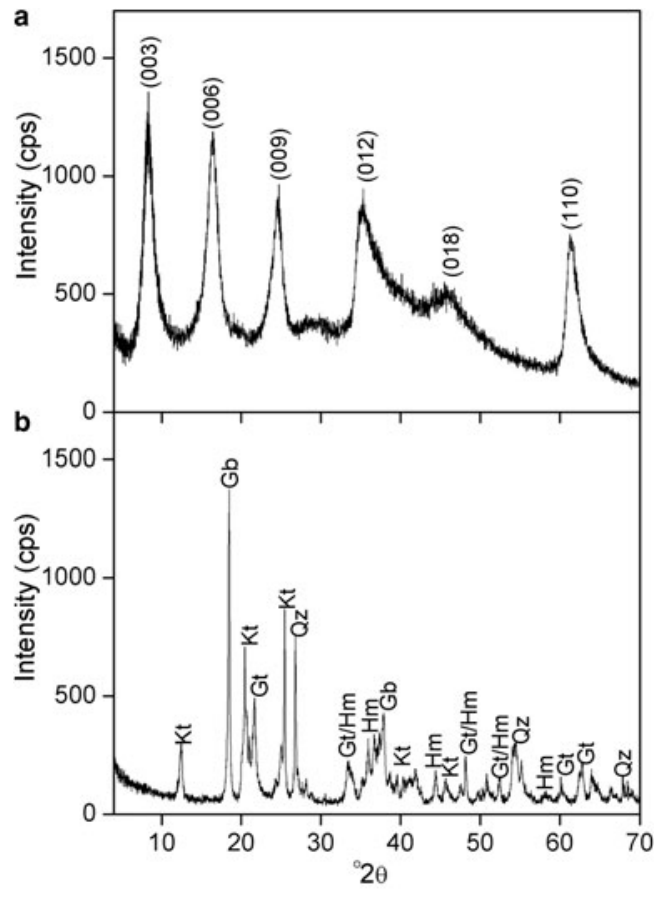

FIG. 1. XRD patterns for (a) $\mathrm{Mg}_{2} \mathrm{Al}-\mathrm{B}-\mathrm{LDH}$ and (b) soil sample; $\mathrm{Kt}=$ kaolinite; $\mathrm{Gb}=$ gibbsite; $\mathrm{Qz}=$ quartz; $\mathrm{Gt}=$ goethite; $\mathrm{Hm}=$ hematite.

$5.0 \mathrm{mmol} \mathrm{L}^{-1} \mathrm{CaCl}_{2}$ solution, heated in a microwave oven (Raij et al., 2001). The available B content was analyzed by UV-Vis spectrophotometry according to the method of López et al. (1993).

\section{Bioassay}

The bioassay to evaluate the use of $\mathrm{Mg}_{2} \mathrm{Al}-\mathrm{B}-\mathrm{LDH}$ as a source of $\mathrm{B}$ for plants was carried out in a greenhouse from October to November 2016.

The treatments were defined by the combination of $2 \times 6$ factorial design, using two sources of $\mathrm{B}\left(\mathrm{Mg}_{2} \mathrm{Al}-\right.$ B-LDH and $\left.\mathrm{H}_{3} \mathrm{BO}_{3}\right)$ and six doses of $\mathrm{B}(0.0,0.5,1.0$, $2.0,3.0$ and $5.0 \mathrm{mg} \mathrm{dm}^{-3}$ of total B). The experimental design was performed in randomized blocks (RBD) with four replications. The experimental units consisted of a plastic pot with capacity for $2.0 \mathrm{dm}^{3}$ of soil. Four sunflower plants (Helianthus annuus Helio 250 hybrid) were cultivated in each pot. This plant was chosen because of its high $\mathrm{B}$ requirement compared to other species.

The liming requirement (LR) calculations were performed with the aim of correcting the acidity and supplying $\mathrm{Ca}$ and $\mathrm{Mg}$. These calculations were determined according to the Basal Saturation method, aiming to raise the saturation to $50 \%$ (Alvarez et al., 1999; Caires et al., 2011). The limestone used was composed of a mixture of $\mathrm{CaCO}_{3}$ and $\mathrm{MgCO}_{3}$, with a $\mathrm{Ca} / \mathrm{Mg}$ ratio of $4: 1$ and Effective Calcium Carbonate Equivalent $(\mathrm{ECCE})=103 \%$. After the complete homogenization of the limestone with the soil, the samples were packed in plastic bags and the soil moisture was raised to $80 \%$ of the field capacity. The incubation period was 25 days, and after 15 days of incubation, humidity was restored to $80 \%$ of the FC. After incubation, the soil sample was air-dried again and sieved through a 2-mm mesh sieve.

The sources and respective doses of $\mathrm{B}$ were homogenized in the total soil volume of each pot. On the same day N, P, K and S nutrients were applied as a nutrient solution. Fertilization with $\mathrm{P}$ and $\mathrm{S}$ was defined according to P-rem (Alvarez et al., 2000; Côrrea et al., 2005), and fertilization with $\mathrm{N}$ and $\mathrm{K}$ as recommended by Novais et al. (1991) and Marcato et al. (2005). The nutrient doses applied to the soil were $450 \mathrm{mg} \mathrm{dm}^{-3}$ of P, $140 \mathrm{mg} \mathrm{dm}^{-3}$ of K, $100 \mathrm{mg} \mathrm{dm}^{-3}$ of $\mathrm{S}$ and $100 \mathrm{mg} \mathrm{dm}^{-3}$ of $\mathrm{N}$. The sources used were $\mathrm{KH}_{2} \mathrm{PO}_{4}, \mathrm{MAP}, \mathrm{CaH}_{2}\left(\mathrm{PO}_{4}\right)_{2}$ and $\left(\mathrm{NH}_{4}\right)_{2} \mathrm{SO}_{4}$.

After 5 days of nutrient application, eight sunflower seeds were sown per pot. The seedlings were thinned seven days after emergence, to leave four plants per pot. The cover fertilizations were divided into two applications during the cultivation, in the form of the nutrient solution, as recommended by Novais et al. (1991) and Marcato et al. (2005). For this phase, the nutrient doses and sources corresponded to $200 \mathrm{mg} \mathrm{m}^{-3}$ of $\mathrm{N}$ (urea), $1.32 \mathrm{mg} \mathrm{dm}^{-3}$ of $\mathrm{Cu} \quad\left(\mathrm{CuSO}_{4} \cdot 5 \mathrm{H}_{2} \mathrm{O}\right), \quad 1.55 \mathrm{mg} \mathrm{dm}{ }^{-3}$ of $\mathrm{Fe}$ $\left(\mathrm{FeSO}_{4} \cdot 7 \mathrm{H}_{2} \mathrm{O}\right), 3.66 \mathrm{mg} \mathrm{dm}{ }^{-3}$ of $\mathrm{Mn}\left(\mathrm{MnSO}_{4} \cdot \mathrm{H}_{2} \mathrm{O}\right)$, $0.15 \mathrm{mg} \mathrm{dm}^{-3}$ of $\mathrm{Mo}\left[\left(\mathrm{NH}_{4}\right)_{6} \mathrm{Mo}_{7} \mathrm{O}_{24}\right]$ and $4.0 \mathrm{mg} \mathrm{dm}^{-3}$ of $\mathrm{Zn}\left(\mathrm{ZnSO}_{4} \cdot 7 \mathrm{H}_{2} \mathrm{O}\right)$.

The plants were cultivated for 45 days. During this period, humidity was maintained at close to $80 \%$ of the FC. The irrigations, with distilled water, were made daily in the upper part of the pots; the $\mathrm{H}_{2} \mathrm{O}$ volume and the frequency of irrigations varied according to the average temperature during the cultivation days. The plant material was dried in a forced circulation oven at $65^{\circ} \mathrm{C}$ for $96 \mathrm{~h}$. After drying, it was weighed, passed through a Wiley mill using a 20-mesh sieve, and stored in paper bags.

The determination of $\mathrm{B}$ in plant tissue was performed according to the method described by Embrapa (2000). After determining the total B content in the aerial part of the plants (Bernardi et al., 2010) from the four plants cultivated in each experimental unit, the $\mathrm{B}$ content in the aerial part was calculated. A sub-sample of $300 \mathrm{~g}$ of soil from each 


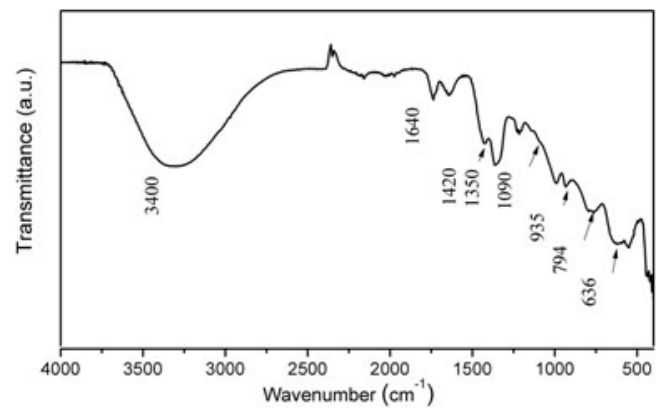

FIG. 2. FTIR/ATR spectrum of $\mathrm{Mg}_{2} \mathrm{Al}-\mathrm{B}-\mathrm{LDH}$.

experimental unit was taken before and after planting for the determination of available $\mathrm{B}$ and soil $\mathrm{pH}$, according to the method described by Raij et al. (2001). The results were submitted to analysis of variance and regression.

\section{RESULTS AND DISCUSSION}

\section{Characterizations}

The XRD patterns for the soil and $\mathrm{Mg}_{2} \mathrm{Al}-\mathrm{B}-\mathrm{LDH}$ are shown in Fig. 1. The soil is a typical Latosol consisting of hematite, gibbsite, goethite and kaolinite (Fig. 1a). The XRD pattern of $\mathrm{Mg}_{2} \mathrm{Al}-\mathrm{B}-\mathrm{LDH}$ is presented in Fig. 1b. The pattern is characteristic of hydrotalcite-type compounds, with (003), (006) and (009) basal peaks at 7.26, 15.6 and $23.6^{\circ} 2 \theta$, respectively. For this material, the basal spacing calculated by the Bragg equation was $12.0 \AA$. This value coincides with the values reported in the literature for intercalation of tetraborate octahydrate ions $\left[\mathrm{B}_{4} \mathrm{O}_{5}(\mathrm{OH})_{4}{ }^{2-}\right] \cdot 8 \mathrm{H}_{2} \mathrm{O}$ between the layers of $\mathrm{LDH}$ (Ay et al., 2011).

The FTIR/ATR spectrum of $\mathrm{Mg}_{2} \mathrm{Al}-\mathrm{B}-\mathrm{LDH}$ is shown in Fig. 2. The presence of the broad band centred at $3400 \mathrm{~cm}^{-1}$ is attributed to the stretching of

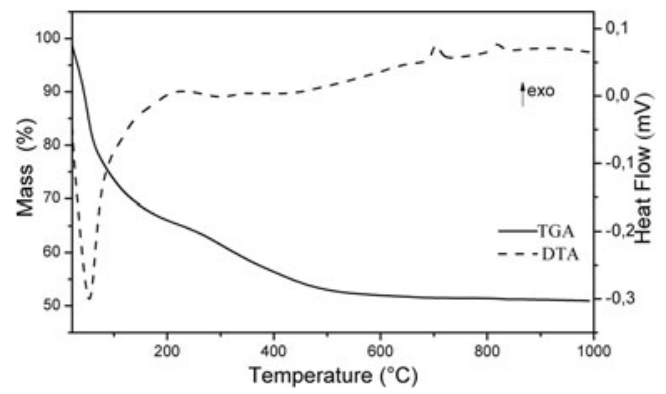

FIG. 3. TGA-DTA of $\mathrm{Mg}_{2} \mathrm{Al}-\mathrm{B}-\mathrm{LDH}$.
TABLE 2. BET specific surface area, pore volume and pore size for the $\mathrm{Mg}_{2} \mathrm{Al}-\mathrm{B}-\mathrm{LDH}$.

\begin{tabular}{lccc}
\hline Sample & $\begin{array}{c}\text { Surface area } \\
\left(\mathrm{m}^{2} \mathrm{~g}^{-1}\right)\end{array}$ & $\begin{array}{c}\text { Pore volume } \\
\left(\mathrm{cc} \mathrm{g}^{-1^{*}}\right)\end{array}$ & $\begin{array}{c}\text { Pore size } \\
(\AA)^{* *}\end{array}$ \\
\hline $\mathrm{Mg}_{2}$ Al-B-HDL & 89.85 & $3.65 \times 10^{-2}$ & 1.98 \\
\hline
\end{tabular}

*HK method; **Non-local density functional theory (NDFT).

the $\mathrm{O}-\mathrm{H}$ bonds of the hydroxyl groups and/or $\mathrm{H}_{2} \mathrm{O}$ molecules. Bands in the region between 1600 and $500 \mathrm{~cm}^{-1}$ are attributed to the various modes of vibration related to the presence of borate anions. More specifically, the bands at 1420 and $1350 \mathrm{~cm}^{-1}, 1090 \mathrm{~cm}^{-1}$, $935 \mathrm{~cm}^{-1}, 794 \mathrm{~cm}^{-1}, 636 \mathrm{~cm}^{-1}$ are attributed to the vibrational modes $v_{a s}(\mathrm{~B} 3-\mathrm{O}), v_{\mathrm{as}}(\mathrm{B} 4-\mathrm{O}), v_{\mathrm{s}}(\mathrm{B} 3-\mathrm{O})$, $v_{\mathrm{s}}(\mathrm{B} 4-\mathrm{O}), v_{\mathrm{s}}(\mathrm{B} 3-\mathrm{O})$, respectively (Ay et al., 2011).

The TGA-DTA curves of $\mathrm{Mg}_{2} \mathrm{Al}-\mathrm{B}-\mathrm{LDH}$ are shown in Fig. 3. The TGA curve presents two events of weight loss. The first event occurs in the temperature range of $22-230^{\circ} \mathrm{C}$ (mass loss of $35 \%$ ). This thermal decomposition is accompanied by an endothermic process, which can be verified by the inflection of the DTA curve at the same temperature range. In this event, the loss of intercalated $\mathrm{H}_{2} \mathrm{O}$ and that adsorbed on the surface of the crystallites occurs. The second event of thermal decomposition occurs in the temperature range $230-670^{\circ} \mathrm{C}$ (mass loss of $13 \%$ ) and is attributed to the dehydroxylation of inorganic layers and the thermal decomposition of the borate. The TGA curve shows only a very small mass loss above $670^{\circ} \mathrm{C}$. At $705^{\circ} \mathrm{C}$ and $820^{\circ} \mathrm{C}$, the DTA curve presented two exothermic events which are produced by recrystallization of $\mathrm{Al}$

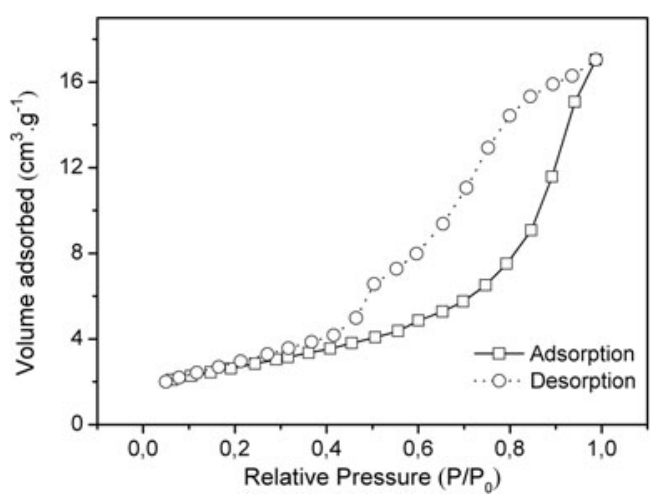

FIG. 4. $\mathrm{N}_{2}$ adsorption-desorption isotherm of $\mathrm{Mg}_{2} \mathrm{Al}-\mathrm{B}-$ LDH. 

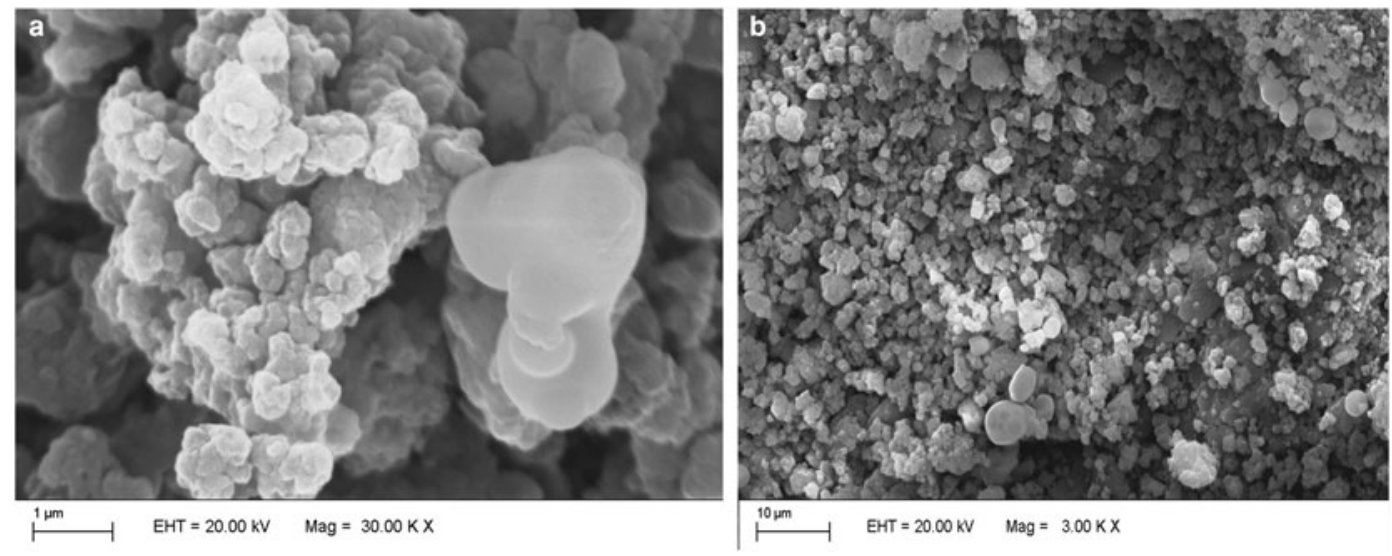

FIG. 5. SEM images of $\mathrm{Mg}_{2} \mathrm{Al}-\mathrm{B}-\mathrm{LDH}$ at two different magnifications.

and Mg borates (Jun et al., 1994; Zhihong et al., 2004; Douy, 2005).

The values of the BET surface area, pore volume and pore size for $\mathrm{Mg}_{2} \mathrm{Al}-\mathrm{B}-\mathrm{LDH}$ are shown in Table 2. The $\mathrm{N}_{2}$ adsorption-desorption isotherm of $\mathrm{Mg}_{2} \mathrm{Al}-\mathrm{B}-\mathrm{LDH}$ is shown in Fig. 4. According to the IUPAC classification, this isotherm is of the IV type, typical of mesoporous materials with pore diameters of $2-50 \mathrm{~nm}$.

The morphology of the $\mathrm{Mg}_{2} \mathrm{Al}-\mathrm{B}-\mathrm{LDH}$ was analysed by means of SEM (Fig. 5). The material consists of spherical aggregates with diameters varying between 1 and $5 \mu \mathrm{m}$.

The total $\mathrm{B}$ content in $\mathrm{Mg}_{2} \mathrm{Al}-\mathrm{B}-\mathrm{LDH}$ as determined by UV-Vis was $45.23 \mathrm{mg} \mathrm{g}^{-1}$ of B per LDH. Previous work reported $q_{\max }$ values of 14.0, 37.90 and $25.5 \mathrm{mg} \mathrm{g}^{-1}$ of $\mathrm{B}$ for $\mathrm{MgAl}-\mathrm{CO}_{3}{ }^{2-}-\mathrm{LDH}, \mathrm{MgAl}-\mathrm{NO}_{3}^{-} \mathrm{LDH}$, and calcined MgAl-LDH, respectively (Ferreira et al., 2006; Kentjono et al., 2010; Isaacs-Paez et al., 2014). Therefore, the amount and total $\mathrm{B}$ determined for $\mathrm{Mg}_{2} \mathrm{Al}-\mathrm{B}-\mathrm{LDH}$ indicates higher incorporation of $\mathrm{B}$ compared to the materials cited in the literature. The chemical formula determined for $\mathrm{Mg}_{2} \mathrm{Al}-\mathrm{B}-\mathrm{LDH}$ was: $\mathrm{Mg}_{2} \mathrm{Al}(\mathrm{OH})_{6}$ $\left[\mathrm{B}_{4} \mathrm{O}_{5}(\mathrm{OH})_{4}{ }^{2-}\right]_{0.38}\left(\mathrm{NO}_{3}^{-}\right)_{0.16}\left(\mathrm{CO}_{3}{ }^{2-}\right)_{0.08} \cdot 5.4 \mathrm{H}_{2} \mathrm{O}$.

\section{Kinetics of boron release in soil}

The results of soil B levels based on the contact time are shown in Fig. 6. The B values for $\mathrm{Mg}_{2} \mathrm{Al}-\mathrm{B}-\mathrm{LDH}$ are lower than those found for $\mathrm{H}_{3} \mathrm{BO}_{3}$. This suggests that $\mathrm{Mg}_{2} \mathrm{Al}-\mathrm{B}-\mathrm{LDH}$ exhibits greater stability than $\mathrm{H}_{3} \mathrm{BO}_{3}$. It was thus noted that $\mathrm{B}$ intercalated in $\mathrm{Mg}_{2} \mathrm{Al}-\mathrm{B}-\mathrm{LDH}$ is released more slowly than that in $\mathrm{H}_{3} \mathrm{BO}_{3}$. It was observed that, in the early days, $\mathrm{Mg}_{2} \mathrm{Al}-\mathrm{B}-\mathrm{LDH}$ stabilizes in the soil, following a sustained release profile.
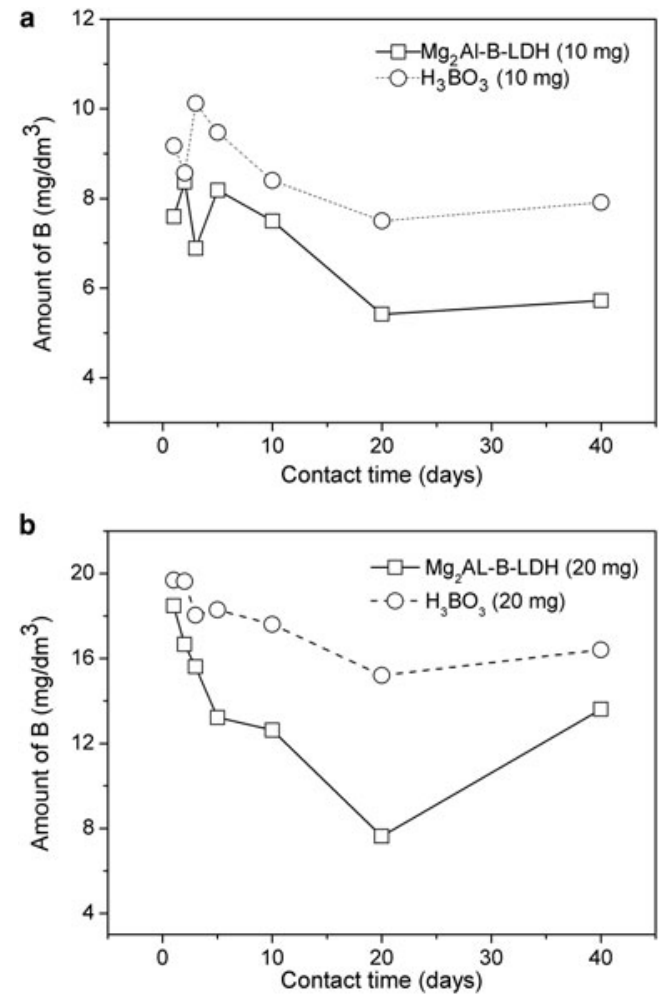

FIg. 6. B available in soil applied in two doses: (a) $10 \mathrm{mg}$ and (b) $20 \mathrm{mg}$ of $\mathrm{B}$, as a function of the equilibrium time for the $\mathrm{Mg}_{2} \mathrm{Al}-\mathrm{B}-\mathrm{LDH}$ and $\mathrm{H}_{3} \mathrm{BO}_{3}$ sources.

\section{Bioassay}

The levels of $\mathrm{B}$ available in the soil indicated that, with increase of the applied doses of $\mathrm{H}_{3} \mathrm{BO}_{3}$ and $\mathrm{Mg}_{2} \mathrm{Al}-\mathrm{B}-\mathrm{LDH}$, the levels of $\mathrm{B}$ increased (Fig. 7). This 

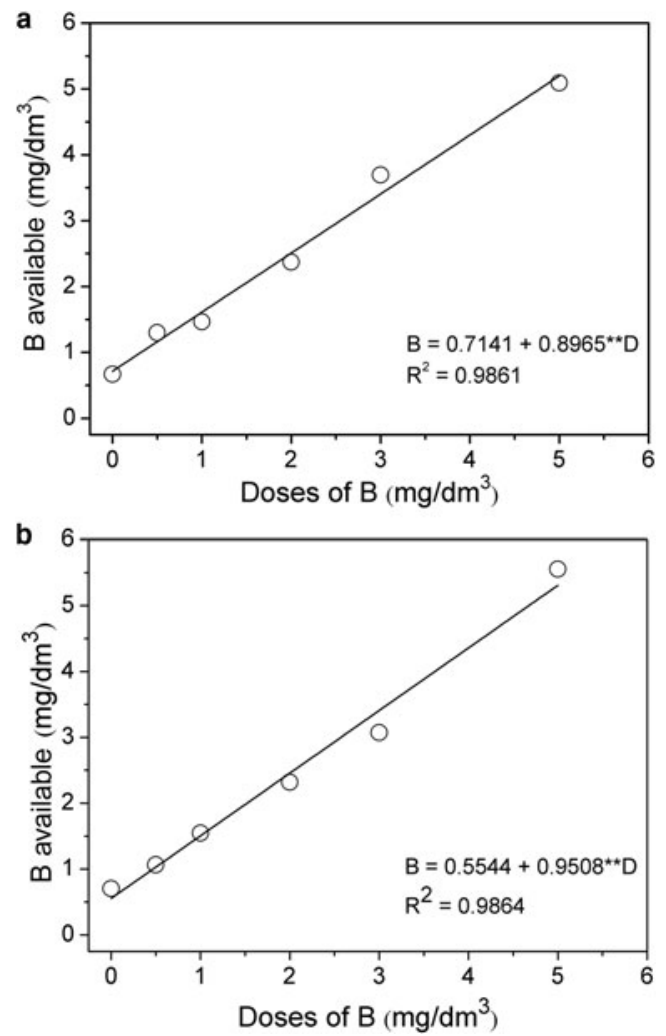

FIG. 7. Simple linear-regression between the available soil $\mathrm{B}$ content before the cultivation of sunflower plants as a function of the applied doses of $\mathrm{B}$ for: (a) Source of B- $\mathrm{H}_{3} \mathrm{BO}_{3}$; (b) Source of B-Mg $\mathrm{Al}-\mathrm{B}-\mathrm{LDH}$. ** = significant at $1 \% ; \mathrm{B}=$ boron available; $\mathrm{D}=$ doses of boron applied.

increase in dose, as demonstrated by the regression analysis, followed a significant linear relationship ( $\mathrm{p}<$ 0.01 ), as expected, as the sunflower plants had not been cultivated yet.

The data for DM production and B content in the aerial parts of the plants are listed in Tables 3 and 4, respectively. For the plants treated with $\mathrm{Mg}_{2} \mathrm{Al}-\mathrm{B}-\mathrm{LDH}$ and $\mathrm{H}_{3} \mathrm{BO}_{3}$, there was an increase in the $\mathrm{DM}$ and $\mathrm{B}$ content in the aerial part of the plants, relative to the treatments that did not receive $\mathrm{B}$. The DM production was not statistically different when comparing the two sources of B used. During the bioassay, it was also noted visually that the sunflower plants showed a similar development for the two sources of B studied. Additionally, it was possible to note plants with symptoms of B deficiency in the treatments without B. The images of the cultivated sunflower plants are presented in Appendices 1 and 2.

The $\mathrm{pH}$ values of the soil before and after the cultivation of sunflower plants are presented in Table 5 . Before cultivation, the average $\mathrm{pH}$ ranged between 5.73 and 6.15. This $\mathrm{pH}$ range, ideal for plant cultivation, chemically classifies the soil as having medium to weak acidity (Alvarez et al., 1999; Caires, et al., 2011). This acidity provided destabilization of the lamellar structure of $\mathrm{Mg}_{2} \mathrm{Al}-\mathrm{B}-\mathrm{LDH}$ and the subsequent release of $\mathrm{B}$. Recent work using a MgAlLDH as a matrix for storage and release of phosphorus presented, in a bioassay carried out with maize (Zea mays), an increase in the soil $\mathrm{pH}$ value based on the dose increase of the P matrix applied (Benício et al., 2016). The release of intercalated anions in LDH depends on the $\mathrm{pH}$ value of medium. At acid $\mathrm{pH}$ value, the $\mathrm{LDH}$ structures are unstable and the release of the intercalated anions occurs due to destruction of the layered material by acid attack, as LDHs are unstable in acid media. Another possibility for the release of intercalated anions is through anionexchange with the anions in the medium (Tronto et al., 2003, 2004; Benício et al, 2016). In this case, as $\mathrm{P}$ is a nutrient required in large quantities for plant growth, the amount of LDH used was greater than the values used for $\mathrm{Mg}_{2} \mathrm{Al}-\mathrm{B}-\mathrm{LDH}$, which favoured the maintenance of the lamellar structure of $\mathrm{LDH}$ intercalated with P. Note that, in this work, a small

TABLE 3. Dry-matter production in the aerial part of the sunflower plants* as a function of the doses and sources of B added to the soil.

\begin{tabular}{|c|c|c|c|c|c|c|c|}
\hline \multirow[t]{2}{*}{ Source } & \multicolumn{6}{|c|}{$\mathrm{B}$ doses $\left(\mathrm{mg} \mathrm{dm}^{-3}\right)$} & \multirow[b]{2}{*}{ Average } \\
\hline & 0.0 & 0.5 & 1.0 & 2.0 & 3.0 & 5.0 & \\
\hline & 55 & & & $\mathrm{~g} / \mathrm{p}$ & & & \\
\hline $\begin{array}{l}\mathrm{H}_{3} \mathrm{BU}_{3} \\
\mathrm{Mg}_{2} \mathrm{Al}-\mathrm{B}-\mathrm{HDL}\end{array}$ & $\begin{array}{l}24.53 \\
2250\end{array}$ & $\begin{array}{r}32.56 \\
20.58\end{array}$ & 32.15 & 32.08 & 34.53 & 33.19 & 31.61 \\
\hline $\mathrm{Mg}_{2} \mathrm{Al}-\mathrm{B}-\mathrm{HDL}$ & 23.59 & 29.58 & 33.59 & 31.76 & 32.93 & 33.00 & 30.74 \\
\hline
\end{tabular}

*There was no significant difference $(\mathrm{p}<0.05)$ between the sources of $\mathrm{B}$. 
TABLE 4. B content in the aerial part of the sunflower plants* as a function of the doses added to the soil.

\begin{tabular}{lccccccc}
\hline Source & \multicolumn{9}{c}{ B doses $\left(\mathrm{mg} \mathrm{dm}^{-3}\right)$} & \\
\cline { 2 - 6 } & 0.0 & 0.5 & 1.0 & 2.0 & 3.0 & 5.0 & Average \\
\hline & 1.76 & 4.27 & 5.80 & 6.92 & 8.65 & 12.06 & 6.58 \\
$\mathrm{H}_{3} \mathrm{BO}_{3}$ & 1.92 & 3.93 & 6.68 & 6.95 & 8.40 & 10.76 & 6.44 \\
$\mathrm{Mg}_{2} \mathrm{Al}-\mathrm{B}-\mathrm{HDL}$ & & & & & & & \\
\hline
\end{tabular}

*There was no significant difference $(p<0.05)$ between the sources of B.

amount of $\mathrm{Mg}_{2} \mathrm{Al}-\mathrm{B}-\mathrm{LDH}$ was applied to plant cultivation, as $\mathrm{B}$ is a micronutrient and thus required in small amounts only. This small amount was not able to change the $\mathrm{pH}$ of the soil (Table 5) to values that might favour the maintenance of the structure of $\mathrm{Mg}_{2} \mathrm{Al}-\mathrm{B}-\mathrm{LDH}$, unlike the result presented by Benício et al. (2016). In addition, plant cultivation itself may acidify the soils according to post-cultivation $\mathrm{pH}$ results (Table 5). Acidification is often associated with the removal of exchangeable bases from the soil (Zinn et al., 2005; Caputo et al., 2016; Zhang et al., 2016), which may favour a lower stability of $\mathrm{Mg}_{2} \mathrm{Al}-$ $\mathrm{B}-\mathrm{LDH}$ and greater nutrient release compared to $\mathrm{H}_{3} \mathrm{BO}_{3}$.

The expected result for the utilization of $\mathrm{Mg}_{2} \mathrm{Al}-\mathrm{B}$ $\mathrm{LDH}$ as a source of $\mathrm{B}$ for plants is that there would be a sustainable release (constant concentration of B over a long period of time) of this micronutrient, more pronounced than that presented by normal $\mathrm{H}_{3} \mathrm{BO}_{3}$. However, this work showed that $\mathrm{Mg}_{2} \mathrm{Al}-\mathrm{B}-\mathrm{LDH}$, applied in the soil with acid $\mathrm{pH}$ values, cannot be characterized as a sustainable release matrix of this micronutrient, as the DM yield and B content in the aerial part of the plants were statistically the same for both sources.

\section{CONCLUSIONS}

The average results of DM yield and B content in the aerial part of the plants between the two sources of $\mathrm{B}$ $\left(\mathrm{Mg}_{2} \mathrm{Al}-\mathrm{B}-\mathrm{LDH}\right.$ and $\left.\mathrm{H}_{3} \mathrm{BO}_{3}\right)$ were similar, and not significantly different from each other. The results obtained for $\mathrm{Mg}_{2} \mathrm{Al}-\mathrm{B}-\mathrm{LDH}$ used as a matrix of sustainable release of $\mathrm{B}$, are probably reflections of the small amount of LDH used in the soil, as B is a micronutrient required in small quantities by the plants. This small amount of $\mathrm{Mg}_{2} \mathrm{Al}-\mathrm{B}-\mathrm{LDH}$ was not sufficient to increase soil $\mathrm{pH}$, which would allow the stability of the LDH structure and would promote the sustainable release of B by means of anionic exchange. The two sources used were solubilized similarly in the soil and released B equally to the plants. Thus, the $\mathrm{Mg}_{2} \mathrm{Al}-\mathrm{B}-\mathrm{LDH}$ used in agricultural soils with normal acid $\mathrm{pH}$ value can be compared to the commercially available, soluble $\mathrm{H}_{3} \mathrm{BO}_{3}$, not as a slow-release source of $\mathrm{B}$ as expected initially. Additional experiments

TABLE 5. Soil $\mathrm{pH}$ as a function of the added $\mathrm{B}$ doses before and after the first cultivation.

\begin{tabular}{llllllll}
\hline Source & \multicolumn{7}{c}{$\mathrm{B}$ dose $\left(\mathrm{mg} \mathrm{dm}^{-3}\right)$} \\
\cline { 2 - 6 } & 0.0 & 0.5 & 1.0 & 2.0 & 3.0 & 5.0 & Average \\
\hline & \multicolumn{7}{c}{ Before the first cultivation } \\
& 5.73 & 5.95 & 5.95 & 5.98 & 5.87 & 6.01 & 5.91 \\
$\mathrm{H}_{3} \mathrm{BO}_{3}$ & 6.15 & 6.08 & 5.95 & 6.03 & 6.01 & 5.85 & 6.01 \\
$\mathrm{Mg}_{2} \mathrm{Al}-\mathrm{B}-\mathrm{HDL}$ & After the first cultivation & & & & \\
$\mathrm{H}_{3} \mathrm{BO} \mathrm{O}_{3}$ & 5.88 & 5.32 & 5.08 & 5.22 & 5.22 & 5.27 & 5.33 \\
$\mathrm{Mg}_{2} \mathrm{Al}-\mathrm{B}-\mathrm{HDL}$ & 5.26 & 5.11 & 5.30 & 5.11 & 4.89 & 5.14 & 5.13 \\
\hline
\end{tabular}


using $\mathrm{M}_{2} \mathrm{Al}-\mathrm{B}-\mathrm{LDH}$ as stores and sources of $\mathrm{B}$ for plant growth in soils at alkaline $\mathrm{pH}$ values are being performed by the authors.

\section{ACKNOWLEDGMENTS}

This study was supported by the Foundation for Research Support of the State of Minas Gerais (FAPEMIG) and the Coordination for the Improvement of Higher Education Personnel (CAPES). This work is a collaborative research project of members of Minas Gerais Chemistry Network (RQ-MG). The authors thank Heliagro for supplying the sunflower seeds used in this research. The authors also thank Vera R.L. Constantino of University of São Paulo for valuable support and useful discussion.

\section{REFERENCES}

Alvarez V.V.H., Novais R.F., Barros N.F., Cantarutti R.B. \& Lopes A.S. (1999) Interpretação dos resultados das análises de solos. Pp. 25-32 in: Recomendação para o uso de corretivos e fertilizantes em Minas Gerais (A.C. Ribeiro, P.T.G. Guimaraes \& V. V.H. Alvarez, editors). 5 Aproximação, Brazil: CFSEMG.

Alvarez V.V.H., Novais. R.F., Dias. L.E. \& Oliveira. J.A. (2000) Determinação e uso do fósforo remanescente. Viçosa. Boletim Informativo. Sociedade Brasileira de Ciência do Solo, 25, 27-33.

Ashekuzzaman S.M. \& Jiang J.Q. (2017) Strategic phosphate removal/recovery by a re-usable $\mathrm{Mg}-\mathrm{Fe}-$ $\mathrm{Cl}$ layered double hydroxide. Process Safety and Environmental Protection, 107, 454-462.

Ay A.N., Zümreoglu-Karan B., Temel A. \& Mafra L. (2011) Layered double hydroxides with interlayer borate anions: A critical evaluation of synthesis methodology and $\mathrm{pH}$-independent orientations in nano-galleries. Applied Clay Science, 51, 308-316.

Bernardi A.C., Monte M.B.D.M., Paiva P.R.P., Werneck C.G., Haim P.G. \& Barros F.D.S. (2010). Dry matter production and nutrient accumulation after successive crops of lettuce, tomato, rice, and andropogongrass in a substrate with zeolite. Revista Brasileira de Ciência do Solo, 34, 435-442.

Benício L.P.F., Silva R.A., Lopes J.A., Eulálio D., Dos Santos M.M., Aquino L.A., Vergutz L., Novais R.F., Costa L.M., Pinto F.G \& Tronto J. (2015) Layered double hydroxides: nanomaterials for applications in agriculture. Revista Brasileira de Ciência do Solo, 39, $1-13$.

Benício L.P.F., Constantino V.R.L, Pinto F.G., Vergutz L., Tronto J. \& Costa L.M. (2016) Layered double hydroxides: new technology in phosphate fertilizers based on nanostructured materials. ACS Sustainable Chemistry \& Engineering, 5, 399-409.

Berber M.R., Hafez I.H. \& Minagawa K. (2014) A sustained controlled release formulation of soil nitrogen based on nitrate-layered double hydroxide nanoparticle material. Journal of Soils and Sediments, 14, 60-66.

Caires E.F., Garbuio F.J., Churka S. \& Joris H.A. (2011) Use of gypsum for crop grain production under a subtropical no-till cropping system. Agronomy Journal, 103(6), 1804-1814.

Cardoso L.P., Celis R., Cornejo J. \& Valim J.B. (2006) Layered double hydroxides as supports for the slow release of acid herbicides, Journal of Agricultural and Food Chemistry, 54, 5968-5975.

Cavani F., Trifirò F. \& Vaccari A. (1991) Hydrotalcite-type anionic clays: Preparation, properties and applications. Catalysis Today, 11, 173-301.

Caputo J., Beier C.M., Sullivan T.J. \& Lawrence G.B. (2016) Modeled effects of soil acidification on longterm ecological and economic outcomes for managed forests in the Adirondack region (USA). Science of the Total Environment, 565, 401-411.

Corrêa R.M., Nascimento C.W.A.D., Souza S.K.D.S., Freire F.J. \& Silva G.B.D. (2005) Gafsa rock phosphate and triple superphosphate for dry matter production and P uptake by corn. Scientia Agricola, 62, 159-164.

Da Silva V., Kamogawa M.Y., Marangoni R., Mangrich A.S. \& Wypych F. (2014) Layered double hydroxides as matrices for nitrate slow release fertilizers, Revista Brasileira Ciência do Solo, 38, 272-277.

De Roy A., Forano C., El Malki K. \& Besse J.P. (1992) Anionic clays: trends in pillaring chemistry. $\mathrm{Pp}$ 108-169 in: Expanded Clays and Other Microporous Solids (M. Occelli \& H. Robson, editors). Springer Science, New York.

Douy A. (2005) Aluminium borates: synthesis via a precipitation process and study of their formation by DSC analysis. Solid State Sciences, 7, 117-122.

Embrapa (2000) Métodos de análise de tecidos vegetais utilizados na Embrapa Solos. Rio de Janeiro. Circular Técnica 6. Embrapa Solos.

Evans D.G. \& Slade R.C.T. (2006) Structural aspects of layered double hydroxides. Pp 1-87 in: Layered Double Hydroxides (X. Duan \& D.G. Evans, editors). Springer: New York.

Everaert M., Warrinnier R., Baken S., Gustafsson J.P., De Vos D. \& Smolders E. (2016) Phosphate-exchanged Mg-Al layered double hydroxides: a new slow release phosphate fertilizer. ACS Sustainable Chemistry \& Engineering, 5, 399-409.

Everaert M., Degryse F., McLaughlin M.J., De Vos D. \& Smolders E. (2017) Agronomic effectiveness of granulated and powdered $\mathrm{P}$-exchanged $\mathrm{Mg}-\mathrm{Al} \mathrm{LDH}$ relative to struvite and MAP. Journal of Agricultural and Food Chemistry, 65, 6736-6744.

Ferreira O.P., De Moraes S.G., Duran N., Cornejo L. \& Alves O. L. (2006) Evaluation of boron removal from water by hydrotalcite-like compounds. Chemosphere, 62 , 80-88. 
Forano C., Hibino T., Leroux F. \& Taviot-Gue'Ho C. (2006) Layered Double Hydroxides. Pp 1019-1128 in: Handbook of Clay Science (F. Bergaya, B.K.G. Theng \& G. Lagaly, editors). Amsterdam: Elsevier.

Ghormade V., Deshpande M.V. \& Pakmikar K.M. (2011) Perspectives for nano-biotechnology enabled protection and nutrition of plants. Biotechnology Advances, 29, 792-803.

Guan Z., Lv J., Bai P. \& Guo X. (2016) Boron removal from aqueous solutions by adsorption - A review. Desalination, 383, 29-37.

Halajnia A., Oustan S., Najafi N., Khataee A. R. \& Lakzian A. (2016) Effects of Mg-Al layered double hydroxide on nitrate leaching and nitrogen uptake by maize in a calcareous soil. Communications in Soil Science and Plant Analysis, 47, 1162-1175.

Imran A., López-Rayo S., Magid J. \& Hansen H.C.B. (2016) Dissolution kinetics of pyroaurite-type layered double hydroxide doped with $\mathrm{Zn}$ : Perspectives for $\mathrm{pH}$ controlled micronutrient release. Applied Clay Science, 123, 56-63.

Isaacs-Paez E.D., Leyva-Ramos R., Jacobo-Azuara A., Martinez-Rosales J.M. \& Flores-Cano J.V. (2014) Adsorption of boron on calcined $\mathrm{Al} \mathrm{Mg}$ layered double hydroxide from aqueous solutions. Mechanism and effect of operating conditions. Chemical Engineering Journal. 245, 248-257.

Jun L., Peng-Sheng S. \& Bai S. (1994) Synthesis and properties of dimagnesium hexaborate heptadecahydrate. Thermochimica Acta, 233, 211-218.

Kentjono L., Liu J.C., Chang W.C. \& Irawan C. (2010) Removal of boron and iodine from optoelectronic wastewater using $\mathrm{Mg}-\mathrm{Al}\left(\mathrm{NO}_{3}\right)$ layered double hydroxide. Desalination, 262, 280-283.

López F.J., Giménez E. \& Hernández F. (1993) Analytical study on the determination of boron in environmental water samples. Fresenius Journal of Analytical Chemistry, 346, 984-987.

Marcato S.R.C., Reissmann C.B., Marques R., Oliveira E. D. \& Taffarel A.D. (2005) Effect of polymers associated with $\mathrm{N}$ and $\mathrm{K}$ fertilizer sources on Dendrathema grandiflorum growth and $\mathrm{K}, \mathrm{Ca}$ and $\mathrm{Mg}$ relations. Brazilian Archives of Biology and Technology, 48, 335-342.

Marschner P. (2012) Marschner's Mineral Nutrition of Higher Plants (3rd edition). 651 pp. Academic Press, New York.

Moraes P.I.R., Tavares S.R., Vaiss V.S. \& Leitão A.A. (2016) Ab initio study of layered double hydroxides containing iron and its potential use as fertilizer. The Journal of Physical Chemistry C, 120, 9965-9974.

Novais R.F., Neves J.C.L. \& Barros N.F. (1991) Ensaio em ambiente controlado. Pp 189-254 in: Métodos de pesquisa em fertilidade do solo (A.J. Oliveira, W.E. Garrido, J.D. Araújo \& S. Lourenço, editors). EMBRA-SEA.

Raij B. van, Andrade J.C., Cantarella H. \& Quaggi J.A. (2001) Análise química para avaliação da fertilidade de solos tropicais. $285 \mathrm{pp}$. Campinas, Instituto Agronômico de Campinas, Brazil.

Rosolem C.A. \& Bíscaro T. (2007) Adsorção e lixiviação de boro em Latossolo Vermelho-Amarelo. Pesquisa Agropecuária, 42, 1473-1478.

Tronto J., Cardoso L.P. \& Valim J.B. (2003) Studies of the intercalation and "in vitro" liberation of amino acids in magnesium aluminium layered double hydroxides, Molecular Crystals and Liquid Crystal, 390, 79-89.

Tronto J., Dos Reis M.J., Silverio F., Balbo V.R., Marchetti J.M. \& Valim J.B. (2004) In vitro release of citrate anions intercalated in magnesium aluminium layered double hydroxides. Journal of Physics and Chemistry of Solids, 65, 475-480.

USDA - Soil Survey Staff (1999) Soil Taxonomy - A Basic System of Soil Classification for Making and Interpreting Soil Survey (2nd edition). 871 pp. USDA, Washington, D.C.

Woo M.A., Kim T.W., Paek M.J., Ha H.W., Choy J.H. \& Hwang S.J. (2011) Phosphate-intercalated C-Felayered double hydroxides: Crystal structure. bonding character. and release kinetics of phosphate. Journal of Solid State Chemistry, 184, 171-176.

Yu S., Wang X., Chen Z., Wang J., Wang S., Hayat T. \& Wang X. (2017) Layered double hydroxide intercalated with aromatic acid anions for the efficient capture of aniline from aqueous solution. Journal of Hazardous Materials, 321, 111-120.

Zhang Y., He X., Liang H., Zhao J., Zhang Y., Xu C. \& Shi X. (2016) Long-term tobacco plantation induces soil acidification and soil base cation loss. Environmental Science and Pollution Research, 23, 5442-5450.

Zhihong L., Mancheng H. \& Shiyang G. (2004) Studies on synthesis, characterization and thermochemistry of $\mathrm{Mg}_{2}\left[\mathrm{~B}_{2} \mathrm{O}_{4}(\mathrm{OH})_{2}\right] \mathrm{H}_{2} \mathrm{O}$. Journal of Thermal Analysis and Calorimetry, 75, 73-78.

Zinn Y.L., Lal R. \& Resck D.V. (2005) Changes in soil organic carbon stocks under agriculture in Brazil. Soil and Tillage Research, 84, 28-40. 

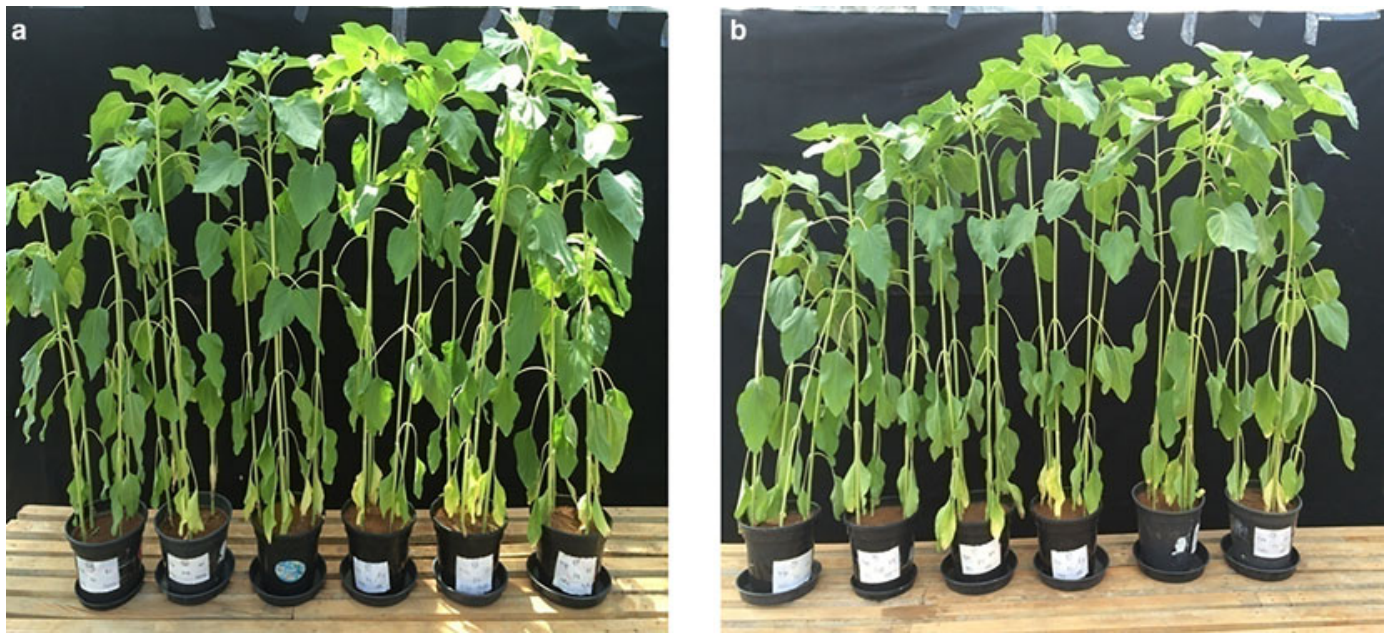

APPENDIX 1. Response of sunflower plants to increasing doses of $\mathrm{B}$ from each of two sources in the soil. From left to right, the pots correspond to doses $0.0,0.5,1.0,2.0,3.0$ and $5.0 \mathrm{mg} \mathrm{dm}^{-3}$ of $\mathrm{B}, \mathrm{H}_{3} \mathrm{BO}_{3}$ (a) and $\mathrm{Mg}_{2} \mathrm{~A} 1$ - $\mathrm{B}-\mathrm{LDH}$ (b).
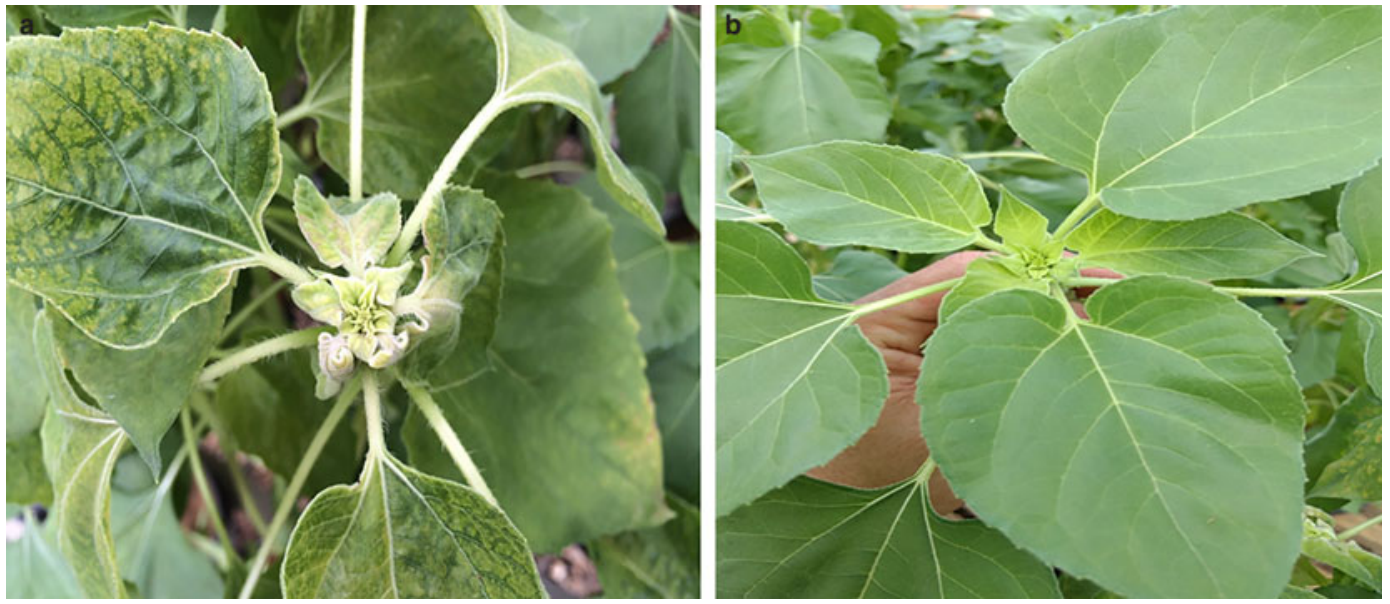

Appendix 2. Sunflower plant with B deficiency symptom at the floral apex (a) and without that symptom (b). 